\section{'NuMex Sunrise', 'NuMex Sunset', and 'NuMex Eclipse' Ornamental Chile Peppers}

\author{
Paul W. Bosland ${ }^{1}$, Jaime Iglesias ${ }^{2}$, and Steve D. Tanksley ${ }^{3}$ \\ Department of Agronomy and Horticulture, New Mexico State University, \\ Las Cruces, NM 88003
}

\begin{abstract}
Additional index words. Capsicum annuum, ristra, ornamental pepper, vegetable breeding
\end{abstract}

The New Mexico Agricultural Experiment Station announces the release of 'NuMex Sunrise', 'NuMex Sunset', and 'NuMex Eclipse', New Mexican-type ornamental chile peppers (Capsicum annuum L.). They are unique in providing alternative mature fruit color in chile peppers. Mature fruits of 'NuMex Sunrise', 'NuMex Sunset', and 'NuMex Eclipse' are yellow, orange, and brown, respectively. The main use for these cultivars will be as ornamental chile peppers.

New Mexicans have traditionally harvested and strung mature red chile peppers into colorful strings or ristras. The ristra is hung near the entrance of the house as a symbol of hospitality. Only pepper types that dehydrate sufficiently to eliminate rotting can be used to make ristras (Sais, 1984). Consequently, pepper types like yellow wax, jalapeño, or bell are not suitable for ristras, because they rot before they dry. Decorations, such as wreaths, made with chile peppers that can be dehydrated are popular in the southwestern United States, and are an important tourist product. Ornamental peppers have become increasingly important as an alternative crop for small farmers. 'NuMex Sunrise', 'NuMex Sunset', and 'NuMex Eclipse' were developed upon request of the New Mexico chile pepper producers.

\section{Origin}

All three cultivars originated from a cross between 'Permagreen' and 'New Mexico 64'. 'Permagreen' produces bell pepper fruits that are green at maturity, and 'New Mexico 6-4' produces long green fruits that are red at maturity. The new cultivars were developed using the pedigree breeding method. Single plant selection was initiated in the $\mathrm{F}_{2}$ and continued through the $\mathrm{F}_{5}$. Each $\mathrm{F}_{5}$ plant selected was homozygous for the horticul-

Received for publication 12 June 1989. Journal article 1395, New Mexico Agr. Expt. Sta., New Mexico State Univ., Las Cruces, NM 88003-0003. The cost of publishing this paper was defrayed in part by the payment of page charges. Under postal regulations, this paper therefore must be hereby marked advertisement solely to indicate this fact. ${ }^{1}$ Assistant Professor.

${ }^{2}$ Research Assistant

${ }^{3}$ Currently, Associate Professor, Dep. of Plant Breeding \& Biometry, Cornell University, Ithaca, NY 14853. N. M.' tural traits important to the New Mexican pepper cultivar. These traits include plant frame, fruit shape, fruit width, immature fruit color, mature fruit color, fruit length, maturity date, and calyx attachment. One trait, pungency, varies within each cultivar. A single plant for each mature color, i.e., yellow, orange, brown, was selected in the $\mathrm{F}_{5}$ generation, and bulking procedures were used in- the $\mathrm{F}_{6}$ generation to increase seed for dis- tribution. No selection pressure was applied after bulking procedures were initiated. The $\mathrm{F}_{3}$ through $\mathrm{F}_{5}$ were grown in an insect-proof greenhouse, whereas the bulked $\mathrm{F}_{6}$ was increased under insect-proof screened isolation cages in the field.

\section{Description}

Each of the lines is green when immature, turning its respective color at maturity. 'NuMex Sunrise', 'NuMex Sunset', and 'NuMex Eclipse' are yellow, orange, and brown at maturity, respectively (Fig. 1). The pods are long, with rounded shoulders, pointed tip, smooth skin, and an attached calyx. They are mildly pungent like 'New Mexico 6-4' and have the typical chile pepper flavor. In Table 1 the mean values for various criteria used in evaluating the progenies are reported. Leaves are sufficiently dense on the plant frame to prevent solar injury to the pods.

\section{Availability}

Small trial samples of open-pollinated seed



Fig. 1. Mature fruits of 'NuMex Eclipse', 'NuMex Sunrise', 'NuMex Sunset', and 'NuMex R Naky'.

Table 1. Plant and fruit characteristics of New Mexican-type chile pepper cultivars at Las Cruces,

\begin{tabular}{lcccccc}
\hline \hline & \multicolumn{2}{c}{ Plant } & & \multicolumn{3}{c}{ Fruit } \\
\cline { 2 - 4 } Cultivar & $\begin{array}{c}\text { Height } \\
(\mathrm{cm})\end{array}$ & $\begin{array}{c}\text { Width } \\
(\mathrm{cm})\end{array}$ & $\begin{array}{c}\text { Length } \\
(\mathrm{cm})\end{array}$ & $\begin{array}{c}\text { Width } \\
(\mathrm{cm})\end{array}$ & $\begin{array}{r}\text { Size } \\
(\mathrm{g})\end{array}$ \\
\hline NuMex Sunrise & $70 \mathrm{c}^{y}$ & $60 \mathrm{a}$ & & $18 \mathrm{ab}$ & $3.7 \mathrm{c}$ & $50 \mathrm{~b}$ \\
NuMex Eclipse & $85 \mathrm{~b}$ & $50 \mathrm{~b}$ & $13 \mathrm{c}$ & $4.9 \mathrm{a}$ & $55 \mathrm{~b}$ \\
NuMex Sunset & $95 \mathrm{a}$ & $60 \mathrm{a}$ & $19 \mathrm{a}$ & $3.6 \mathrm{c}$ & $50 \mathrm{~b}$ \\
NuMex R Naky & $75 \mathrm{c}$ & $65 \mathrm{a}$ & $17 \mathrm{~b}$ & $4.4 \mathrm{~b}$ & $70 \mathrm{a}$ \\
New Mexico 6-4 & $75 \mathrm{c}$ & $65 \mathrm{a}$ & $17 \mathrm{~b}$ & $4.3 \mathrm{~b}$ & $69 \mathrm{a}$ \\
\hline
\end{tabular}

${ }^{2}$ Means represent 10 plants or 25 fruits sampled in each of five replications each. year for three years. 'Mean separation in columns by a protected Fisher's LSD test, 0.05 level. 
are available for distribution to interested research and extension personnel. Address trial requests for seed to the senior author. Commercial distribution of foundation seed will be through the New Mexico Crop Improvement Assn., New Mexico State Univ., Box 3CI, Las Cruces, NM 88003; phone 505/

\section{Literature Cited}

Sais, J.R. 1984. Making chile ristras. New Mexico State Univ. Coop. Ext. Bul. 400 H-2. 